\title{
Survey
}

\section{The Application of EU Competition Law in the Pharmaceutical Sector}

\author{
David W. Hull and Michael J. Clancy*
}

\section{Introduction}

This survey article discusses the major EU competition law developments in the pharmaceutical sector from 1 November 2015 through 31 December 2016. Section 2 addresses cases on restrictions of competition from generic suppliers, including the Lundbeck and Servier cases now on appeal to the EU courts, the new GlaxoSmithKline (GSK) decision in the UK, the European Commission's annual patent settlement monitoring exercise and the judgement of the French Supreme Court in Sanofi-Aventis. Section 3 covers the recent cases prosecuting excessive pricing, including the Aspen case in Italy and the Pfizer/Flynn and Actavis cases in the UK. Section 4 addresses the cases before the EU Court of Justice concerning licensing agreements, including Hoechst/Genentech and Roche/ Novartis. Section 5 addresses recent decisions, judgements, and regulations in EU Member States on the ongoing issue of parallel trade. Finally, Section $6 \mathrm{cov}-$ ers the results of sector inquires reported by competition authorities in five EU Member States covering a broad range of issues arising in the pharmaceutical sector.

\section{Restriction of competition from generic suppliers}

\section{A. Reverse-payment patent settlements}

\section{Lundbeck}

In September 2016, the General Court issued its judgements in its first ever case on reverse-payment patent settlements in the pharmaceutical sector, upholding the Commission's decision against Lundbeck, the Danish pharmaceutical company, and the generic manufacturers Alpharma, Merck KGaA/Generics UK, Arrow, and Ranbaxy. ${ }^{1}$

\footnotetext{
* David Hull is a partner and Michael Clancy is a counsel in Van Bael \& Bellis, Brussels. They would like to thank their colleague, Charlotte Woolfson, for her invaluable help with this survey.

1 Case T-472/13, Lundbeck v. Commission ('Lundbeck Judgment'), Case T-471/13; Xellia Pharmaceuticals and Alpharma v. Commission, Case
}

\section{Key Points}

- The main activity continues to be in the area of reverse-payment patent settlements (the Lundbeck and Servier cases are winding their way through the appeals process at the EU Courts; and a new decision was issued against GlaxoSmithKline in the UK).

- On the contentious issue of the pricing of medicines, the UK and the Italian competition authorities issued decisions against alleged excessive pricing.

- There have also been new developments in the areas of licensing and distribution/parallel trade, and national competition authorities have published results of recent sector inquiries in five EU Member States.

The settlement agreements at issue involved Lundbeck's blockbuster anti-depressant citalopram, for which the compound patent had expired, but Lundbeck still had patents covering its manufacturing processes. The Commission's decision indicates that, around the time when the generic suppliers were about to enter the market, Lundbeck threatened legal action against the generic suppliers for violation of its process patents. Thereafter, Lundbeck and the generic suppliers entered into settlement agreements, in which Lundbeck made payments to the generic suppliers and they allegedly agreed not to enter the market for the duration of the agreement.

On appeal, the General Court upheld the Commission's decision in all respects and there is little independent analysis of the decision-on each point, the General Court essentially repeated the Commission's analysis and said it agreed. While the circumstances and agreements for each settlement were different, and thus each judgement by the General Court-one for each of Lundbeck 
and the generics-is different, there are certain common core issues that are important from the standpoint of the development of competition law and policy. These are discussed briefly below.

- Potential competition. A threshold issue in each case was whether Lundbeck and the generic were potential competitors. According to the General Court, a generic is a potential competitor as long as it has taken concrete steps to enter the market such as obtaining a marketing authorisation and securing a source of supply. The Court rejected the argument raised by Lundbeck and numerous generics that a generic could not be a potential competitor because Lundbeck's process patent must be presumed to be valid and, thus, if the generic entered the market, it would do so in violation of the patent. The Court emphasised that 'at risk' entry is not illegal and that the generic entrant might eventually be successful in having the patent invalidated. According to the Court, 'the presumption of validity cannot be equated with a presumption of illegality of generic products validly placed on the market which the patent holder deems to be infringing the patent. ${ }^{2}$

- 'By object' infringement. The General Court found that the settlements constituted restrictions of competition 'by object' so that it was not necessary to establish anticompetitive effects. The General Court found that the settlements were equivalent to standard market-sharing agreements that had long been condemned under EU competition law, rejecting the argument of Lundbeck and the generics that the existence of a patent meant that the settlements were much different from plain-vanilla market-sharing agreements and, thus, a 'by object' approach was inappropriate. As with its analysis of potential competition, the General Court gave little weight to Lundbeck's patent, emphasising that there was uncertainty concerning its validity as no court had yet issued a definitive ruling on that issue.

- Payment. The payments made by Lundbeck to the generics were critical to the finding of a restriction by object. According to the Commission, when a settlement is made without a payment or other transfer of value from the originator to the generic, it is unlikely to raise competition concerns as the settlement likely would be the result of the parties' independent assessments of the patent situation. In contrast, where there is a payment, it may well be that it is the payment rather than the patent that causes the generic to agree not to enter the market for a certain period. The General Court agreed with the Commission that the core problem with a payment is that it eliminates the uncertainty faced by the originator concerning whether its patent is valid and ensures that there will be no entry by the generic. The General Court rejected the argument that the payment may simply reflect an asymmetry of risk as between the originator and the generics in that the originator has much more to lose if the patent is struck down or held not to be infringed.

Lundbeck and the generic suppliers have appealed the judgements to the Court of Justice. These appeals offer the Court of Justice a superb occasion to provide guidance on how to strike the correct balance between intellectual property and competition law. The arguments on appeal are likely to centre on the role of the patent in both the analysis of potential competition and whether there is a restriction by object. The General Court's judgement seems to endorse a low threshold for the existence of potential competition as it seems sufficient that the generic has taken steps to enter the market. The existence of a patent would rarely, if ever, be viewed as excluding potential competition as the generic would always have at least some chance of winning in any eventual patent litigation. Likewise, the General Court seems to gloss over the patent in concluding that there is a restriction of competition by object. This conclusion seems questionable as it necessarily assumes that the originator would have little chance of excluding the generic in the absence of the agreement. Lundbeck and the generics will undoubtedly seek to convince the Court of Justice that the General Court failed to analyse properly the role of the patent in reaching its conclusions.

This case also offers the Court of Justice an unusually good opportunity to clarify the scope and meaning of a 'by object' restriction. As it seemed to take the combination of a sector enquiry, a 10-year investigation and a 466-page decision for the Commission to reach the conclusion that the settlement agreements at issue in this case infringed Article 101, it would seem at least questionable whether they should be treated as 'by object' restrictions that 'by their very nature' are restrictive of competition, particularly in light of the Court of Justice's ruling in Cartes Bancaires, ${ }^{3}$ in which it seemed to narrow 
the scope of the 'by object' restriction. Moreover, it would seem at least debatable whether the agreements had the kind of high likelihood of restricting competition that characterises restrictions by object given that the available evidence seemed to suggest that Lundbeck had a reasonable chance ( 40 per cent to 50 per cent) of winning the patent litigation.

\section{Servier}

In Servier, the Commission imposed a fine of $€ 331$ million on Servier, the French pharmaceutical company, and fines totalling $€ 96$ million on five generic manufacturers-Unichem, Matrix (now Mylan), Teva, Krka, and Lupin. This decision is currently on appeal to the General Court. ${ }^{5}$ The agreements involved Servier's bestselling blood pressure medicine, perindopril. Servier's basic molecule patents had expired in 2003, but it still held a number of patents related to the manufacturing process and the product's formulation, which the Commission described as 'secondary' patents. Generic manufacturers were challenging these patents before various courts and, at the same time, preparing to enter the market.

The Commission's decision in Servier differs from the Lundbeck decision in two basic respects. First, while the Commission only analysed the settlement agreements under a 'by object' test in Lundbeck, it hedged its bets and also applied an 'effects' test in Servier. Second, the Commission found that, in addition to entering into agreements that restricted competition in violation of Article 101, Servier's conduct constituted an abuse of its dominant position in violation of Article 102. This is the first time that the Commission has applied Article 102 to late life cycle management strategies since its decision in AstraZeneca, and is therefore useful in understanding its thinking. The Commission began its analysis by emphasising that a strategy designed to protect an originator's market position against generic entry is 'generally legitimate to the extent it resorts to measures representing competition on the merits,' which it described as competition on product quality and the strategic use of IPRs and the patent system. ${ }^{6}$ In contrast, a dominant company's use of measures that deviate from competition on the merits and are capable of pro-

4 Case AT.39612, Servier, Decision of 9 July 2014.

5 See Cases T-705/14, Unichem Laboratories $v$ Commission, T-701/14, Niche Generics $v$ Commission, T-691/14, Servier and Others $v$ Commission, T-684/14, Krka v Commission, T-682/14, Mylan Laboratories and Mylan v Commission, T-680/14, Lupin v Commission, T-679/14, Teva UK and Others $v$ Commission, T-677/14, Biogaran v Commission.

6 Servier, para. 2766. ducing foreclosure effects will be subject to antitrust scrutiny.

Applying these principles to Servier's late life cycle management strategy, the Commission found that Servier had abused its dominant position by engaging in a 'single and continuous exclusionary strategy' that consisted of both acquiring technology that would have allowed generic manufacturers to make a product that did not infringe Servier's process patents and the conclusion of the settlement agreements. ${ }^{7}$ In finding that these features of Servier's strategy were abusive, the Commission emphasised that they took place in the context of a broader strategy aimed at curbing generic entry that included the creation of a patent thicket and efforts to convince regulators to adopt stricter product specifications that favoured Servier's product. While the Commission did not establish that these practices contributed to foreclosure effects, it nevertheless found them to be pertinent to its analysis insofar as they explained why competition from generics was limited to certain avenues that Servier then proceeded to shut off through its acquisition of technology and the settlement agreements. ${ }^{8}$ This approach seems inconsistent with the Commission's declaration that strategic use of patents is generally not problematic and is disturbing in that it seems to suggest that it will be easier to find that conduct is abusive if it takes place in the context of an entirely legitimate IP and regulatory strategy aimed at combatting generic competition.

The abuse identified in Servier is also interesting in that the Commission went out of its way to construct an abuse that did not consist of a single action taken in isolation, but rather was a combination of various activities-the acquisition and the settlements. To link these activities, the Commission borrowed the phrase 'single and continuous act' so familiar in the context of its cartel decisions. ${ }^{9}$ It underscored that the technology acquisition and the settlements were 'intertwined' 10 and 'complementary," forming a 'clear pattern'12 of conduct where Servier targeted potential entrants to remove the competitive threat. In the Commission's view, the technology acquisition and the settlements were necessary complements to a successful exclusionary strategy as they shut off the two principle routes to market for

\footnotetext{
7 Servier, para. 2774.

8 Servier, para. 2772.

9 Servier, paras 2962-2963 and footnote 3804.

10 Servier, para. 2783.

11 Servier, para. 2777.

12 Servier, para. 2794
} 
generics-inventing around the patented process or convincing a court to issue a finding of invalidity or non-infringement. ${ }^{13}$

In concluding that the technology acquisition contributed to the foreclosure effects of its single and continuous exclusionary strategy, the Commission found that Servier did not acquire the technology to improve its own production processes (as there was evidence that Servier did not use the technology), but rather to reinforce its thicket of blocking patents. ${ }^{14}$ The Commission examined the technological landscape in some detail and found that the technology acquired by Servier was the most advanced in terms of potential to bring a product to market and, thus, represented the most immediate competitive threat to Servier. By acquiring the technology, Servier foreclosed competitors from the market.

Turning to the settlements, the Commission found that they fell outside competition on the merits and also contributed to the foreclosure effects of Servier's strategy. According to the Commission, Servier engaged in unilateral abusive conduct by using the profits it reaped in a market where it was dominant to buy off competitors. ${ }^{15}$ The Commission highlighted that the settlements were a 'chain of agreements which were mutually reinforcing' 16 and that they formed part of a pattern pursuant to which Servier 'systematically targeted' close potential competitors. ${ }^{17}$

All of these issues are likely to feature prominently in the eventual judgements of the General Court in the appeals that have been filed by Servier and the generics against the Commission's decision. In light of the strong views held by those on each side of this debate, it would seem likely that the ruling of the General Court would be appealed to the Court of Justice, which means that it could be a number of years before these issues are finally settled.

\section{GlaxoSmithKline}

Taking its cue from the Commission's decisions in Servier and Lundbeck, the Competition and Market Authority (CMA) imposed fines totalling $£ 44.99$ million on GSK and two generic manufacturers in February 2016 for entering into reverse-payment patent settlements in connection with the anti-depressant drug paroxetine. ${ }^{18}$

\footnotetext{
13 Servier, para. 2794.

14 Servier, para. 2776.

15 Servier, para. 2933.

16 Servier, para. 2942.

17 Servier, para. 2945.

18 Paroxetine, Case CE-9531/11 (12 February 2016).
}

In 2001, a number of generic manufacturers sought to enter the UK market with a generic version of GSK's blockbuster Seroxat. At the time, Seroxat was one of the world's most popular anti-depressants and one of GSK's best-selling products. GSK challenged these pharmaceutical companies alleging that generic products were infringing its patents. GSK concluded agreements notably with Generics (UK) Limited and Alpharma where GSK agreed to make payments and other value transfers totalling over $£ 50$ million. In turn, GUK and Alpharma agreed to refrain from entering the UK market for paroxetine from 2002 to 2004.

The CMA held that these settlement agreements avoided competition from the threat independent generic entry could offer and deprived the National Health Service of the price falls that normally result from generic competition. Like the European Commission in Servier, the CMA relied on both a 'by object' and 'by effect' theories in finding an infringement of Article 101. In addition, the CMA found that GSK had abused its dominant position in violation of Article 102 as the payments to the generics meant that GSK took actions that were different from those characteristic of 'normal competition.'

The CMA's decision is now on appeal to the UK's Competition Appeal Tribunal. ${ }^{19}$ As the CMA's decision is largely consistent with the approach of the European Commission in Lundbeck and Servier and, given the similarity of the issues, it will be interesting to see how the UK litigation plays out in light of the concurrent appeals of the EU cases in Luxembourg.

\section{Patent settlement monitoring report}

The Commission continues to monitor patent settlements in the pharmaceutical sector. Each year, the Commission requests originator and generic companies to submit copies of all patent settlement agreements covering EU/EEA markets concluded during the previous calendar year together with related agreements. The apparent aim of this annual monitoring exercise is to identify reverse-payment patent settlements and other settlements that could delay generic entry, such as those that contain restrictions extending beyond the geographic or material scope of the patent.

19 Case no. 1251/1/12/16, Generics (UK) Limited v. Competition and Markets Authority, Case no. 1252/1/12/16, GlaxoSmithKline PLC v. Competition and Markets Authority, Case no. 1253/1/12/16, Xellia Pharmaceuticals APS and Alpharma LLC v. Competition and Markets Authority, Case no. 1254/1/12/16, Actavis UK Limited v. Competition and Markets Authority, Case no. 1255/1/12/16, Merck KGAA v. Competition and Markets Authority. 
With language essentially verbatim from previous monitoring reports, the Seventh Monitoring Report ${ }^{20}$ discusses the main categories of settlements and then provides an overview of the replies submitted by companies and an analysis of the main characteristics of the settlements falling within particular categories. The report also sets out statistics for the latest year, although these statistics are of little use in understanding what is actually happening. For example, the Report states that the number of settlements has increased, but this is a meaningless statistic unless it is compared to the number of cases litigated, which the Report fails to do.

Perhaps the most troubling aspect of the monitoring report is that the categories used to classify settlements in terms of the degree of competition law risk attached to them provide little useful information and arguably have a chilling effect on settlements that could be procompetitive to the extent that they would allow early generic entry. These categories had their origin in the Commission's Report on the Pharmaceutical Sector Inquiry, which is somewhat ironic given that, in this Report, the Commission explicitly disavowed reaching any conclusions concerning the application of competition law in the pharmaceutical sector. ${ }^{21}$ Settlements falling in Category A and Category B.I are considered to be generally unproblematic, which is not surprising as Category A settlements are those that allow immediate market entry by the generic, and those in Category B.I are those where there is no value transfer from the originator, i.e. where the generic agrees to enter after patent expiry. It is questionable whether settlements in these categories are settlements at all in the sense that the one side or the other has capitulated entirely.

Settlements falling in the remaining categoryCategory B.II-which do not allow immediate entry by the generic and involve a value transfer from the originator to the generic are deemed the most likely to raise competition law concerns. The problem with this category is that it includes almost every form of settlement that would seem to fall within the normal definition of the term and, thus, risks discouraging companies from entering into meaningful settlements at all, including those that would allow early entry. For example, this category includes a common form of settlement that would seem to be benign in most circumstances: early entry by the generic. The Commission itself admits that such settlements are 'not likely to attract the highest

20 European Commission, 7th Report on the Monitoring of Patent Settlements, December 2016.

21 European Commission, Executive Summary of the Pharmaceutical Sector Inquiry Report, July 2009, p. 6 (It is important to note underline that ... [the report] does not identify individual cases of wrongdoing or provide any degree of antitrust scrutiny. ${ }^{, 22}$ Instead of using such vague language, it would be helpful if the Commission clearly stated that such a settlement would be unlikely to raise concerns. More generally, after 7 years of monitoring as well as having adopted decisions in Lundbeck (confirmed by the General Court) and Servier, it would seem that the Commission has enough experience under its belt that it could issue some form of guidance to companies that put meat on the bones of the sparse guidance found in its monitoring reports.

\section{B. Denigration}

On 18 October 2016, the French Supreme Court issued its judgement in the Sanofi-Aventis case concerning denigration of generic competitors. ${ }^{23}$ In the judgement, the Court affirmed a prior judgement of the Paris Court of Appeals, ${ }^{24}$ which in turn upheld the decision of the French competition authority finding that SanofiAventis had abused its dominant market position and imposing a fine of $€ 40.6$ million.

In its 2013 decision, the competition authority found that Sanofi-Aventis had engaged in a marketing campaign that systematically discouraged the use of generic versions of Sanofi-Aventis' blockbuster Plavix by highlighting that the generics used different salts from the original version and that they were not indicated for use in combination with aspirin for acute coronary syndrome (ACS). The authority considered this marketing campaign to be misleading. While Sanofi-Aventis did not claim that the use of different salts could affect the efficacy or safety of a generic, or that the use of generics with aspirin to treat ACS was dangerous, it implied as much, which created doubts in the minds of doctors and pharmacists concerning generics. As doctors are reluctant to change their prescribing habits and are risk averse, any dissemination of negative information or insinuation that a generic product may present risk will be sufficient to convince doctors not to prescribe it and pharmacists not to provide it to the patient when given a choice.

In essence, Sanofi-Aventis was found to have misled by omission. It had failed to explain that the generics used a different salt because of Sanofi-Aventis's patent over its salt and that this use of a different salt did not affect the safety or efficacy of the generic. Similarly, it had failed to explain that generics did not have an indication for the use of the drug in combination with

\footnotetext{
guidance on the compatibility of the practices examined with the EC competition rules).

22 7th Report on the Monitoring of Patent Settlements, para. 12.

23 French Supreme Court, Case no. 890 (18 October 2016).

24 Paris Court of Appeal, Case no. 2013/12370 (18 December 2014).
} 
aspirin to treat ACS because Sanofi-Aventis had a patent over this use.

Before the French Supreme Court, Sanofi-Aventis argued that it was simply providing information about the existence of its patent over a salt used in the original version of the drug (which meant that the generic had to use a different salt) and a patent over the use of the drug with aspirin to treat ACS (which meant that the generic could not be used with aspirin to treat ACS). This could not be construed as denigration given that this information was based on objective and verified data, a fact which had been acknowledged by the Court of Appeals. Sanofi-Aventis further contended that its communication aimed at presenting its drug in an objective and sufficiently comprehensive manner so as to enable healthcare professionals to verify this information and to form their own opinion on the therapeutic value of the drug. As such, Sanofi-Aventis argued that the Court of Appeals erred in law by ruling that the information was misleading when it had, at the same time, acknowledged that the data communicated were objective and verified.

In its judgement, the French Supreme Court confirmed the strict approach taken by the competition authority and affirmed by the Court of Appeals towards communications made by originators to promote their products in the face of generic competition. The Supreme Court recognised that Sanofi-Aventis knew from experience that healthcare professionals are risk averse. It also agreed with the Court of Appeals that, in light of this risk aversion, any dissemination of negative information or insinuation about the quality of a drug may suffice to discredit it before doctors. Further, the Court noted that the campaign had an effect on the market as a number of doctors wrote 'non-substitutable' on prescriptions and pharmacists substituted Sanofi-Aventis's own generic version of its drug rather than that of other generics.

The Supreme Court thus found that the Court of Appeals did not err in law, as a significant number of healthcare professionals had actually been influenced by the information communicated by Sanofi-Aventis which held a dominant position on the relevant market. As such, the denigration practice carried out by SanofiAventis had the effect of limiting generic entry onto the market, in breach of competition law.

This judgement confirms that originators need to be careful in raising concerns about generics, as a marketing campaign may be held to be abusive if it creates unsubstantiated doubt in the minds of doctors and pharmacists about the quality of the generic. It also shows that originators need to be careful in seeking to prevent offlabel use of generics that would allow them to compete with the originator's drug.

\section{Excessive pricing}

Competition authorities have continued to investigate pricing strategies of originator companies, with the most important developments this year in the area of excessive pricing.

\section{A. Policy considerations}

Although competition authorities frequently face strong public and governmental pressure to pursue pharmaceutical suppliers for charging excessive prices, they are generally reluctant to launch such cases because it is difficult to determine the 'correct' price, intervention on pricing may chill innovation, and national health authorities and other payors often have strong buyer power that mitigates competition law concerns. This reluctance is illustrated by the European Commission's decision not to open an investigation into allegations of excessive prices for Hepatitis $\mathrm{C}$ drugs, despite pressure from members of the European Parliament. In response to two parliamentary questions, the Commission noted that Member States have both economic bargaining power and regulatory powers to control the prices of pharmaceutical products, and that such powers were being used to limit the prices of the Hepatitis C drugs. ${ }^{25}$

However, as illustrated by the Aspen, Pfizer/Flynn Pharma and Actavis cases discussed below, competition authorities are willing to pursue excessive pricing cases where the product has been on the market for some time and there is a drastic price increase. In these circumstances, the 'old' price of the product provides a ready point of comparison for determining whether the new price is excessive. Moreover, as the product has been on the market for some time, the originator has presumably had time to recoup its R\&D costs, which mitigates the concern that intervention on pricing could chill innovation.

\section{B. Aspen}

On 29 September 2016, the Italian Competition Authority imposed a fine of $€ 5.2$ million on Aspen

25 European Commission, Response to Parliamentary Question P-008636/ 2014 (22 December 2014) and Response to Parliamentary Question E-000261-15 (31 March 2015). 
Pharma for abusing its dominant position by charging excessive prices for the supply of certain drugs used in the treatment of cancer, which were known as 'Cosmos' drugs. ${ }^{26}$ These drugs had been on the market several decades and all patent rights had expired. Aspen bought the trade mark and marketing rights to these drugs from GSK in 2009. The competition authority found that Aspen had increased prices 300 per cent to 1,500 per cent as compared with the prices previously charged by GSK in an effort to bring the prices in line with those charged for the drugs in other Member States.

In finding that Aspen's price increases were abusive, the competition authority applied the test for excessive pricing first developed by the EU Court of Justice in United Brands. First, the authority engaged in an indepth economic analysis of the difference between the new prices of the Cosmos drugs and their production costs, and concluded that it was significant. In its analysis, the authority took note of the absence of any investments by Aspen in order to improve the quality and innovation of the products or to promote their sale.

Second, the authority examined whether the significant difference between the prices and costs could be justified, and concluded that it could not. In reaching this conclusion, it stressed that the drugs were life saving and that there was no substitute; that Aspen was a generics company and not engaged in research and development of drugs and its business model was to acquire existing drugs and exploit market niches by raising prices; and that Aspen's price increase had used up a significant amount of the national health budget.

One aspect of the competition authority's decision that could be particularly troubling to pharmaceutical companies is its willingness to examine Aspen's negotiating strategy vis-à-vis AIFA, the Italian health authority, as part of its analysis of whether Aspen's conduct was abusive. According to the authority, Aspen adopted a very aggressive negotiating strategy towards AIFA in order to obtain a favourable deal. It first requested AIFA to re-categorise Cosmos drugs so that their prices would no longer be regulated by agreement and could instead be set freely by Aspen, with the costs being borne by patients, as opposed to being reimbursed under the national health system. When AIFA refused,

26 Italian Competition Authority, Case A-480 (29 September 2016).

27 Competition and Market Authority, Press Release, CMA fines Pfizer and

Flynn $£ 90$ million for drug price hike to NHS, December $2016<\mathrm{https} / / /$

www.gov.uk/government/news/cma-fines-pfizer-and-flynn-90-million-fordrug-price-hike-to-nhs $>$.

28 Pfizer, Press Release, Pfizer statement on Competition and Markets Authority's infringement decision, 7 December $2016<$ http://www.pfizer.co.
Aspen demanded a substantial upward revision of prices. Aspen also threatened to reduce or terminate supplies of the drugs to the Italian market if AIFA refused to agree to the price increase.

\section{Pfizer/Flynn}

On 7 December 2016, the CMA imposed a $£ 84.2$ million fine on Pfizer and $£ 5.2$ million fine on Flynn Pharma for allegedly charging excessive and unfair prices for phenytoin sodium capsules, an epilepsy drug. ${ }^{27}$ It also ordered the companies to reduce their prices.

Prior to September 2012, Pfizer had sold phenytoin sodium capsules at a regulated price to wholesalers under the brand name Epanutin. However, in September 2012, Pfizer sold the UK distribution rights for Epanutin to Flynn Pharma. Flynn promptly de-branded or 'genericised' the drug, which meant that its price was no longer subject to regulation. Since 2012, Pfizer supplied phenytoin sodium capsules at prices that were not only significantly higher than the prices it had charged previously (between 780 per cent and 1,600 per cent), but that were also significantly higher than the prices it charged in any other European country. Flynn, in turn, increased the prices charged to wholesalers and pharmacies by 2,300 per cent to 2,600 per cent.

In finding that these price increases were excessive, the CMA highlighted that the drug had been on the market for many years and that there had been no recent innovation or significant investment. Thus, as with the Aspen case, the CMA did not believe that its intervention would deter innovation as the originator had already had plenty of time to recoup its investment.

Pfizer argued that it needed to increase prices because Epanutin was loss-making before it was de-branded. However, the CMA rejected this argument, pointing out that such losses would have been recovered within two months of the price increase.

Both Pfizer and Flynn Pharma have announced that they will appeal the CMA's decision. ${ }^{28}$ Both companies emphasised that the prices charged for their drug were less than alternative equivalent drugs on the UK market that had long been regulated and had appeared to be acceptable to the UK Department of Health.

uk/latest-news/2016-12-07-pfizer-statement-competition-and-marketsauthority\%E2\%80\%99s-infringement-decision>; Flynn Pharma, Press Release, CMA issue infringement Decision against Flynn, 7 December 2016 $<$ http://www.flynnpharma.com/about-us/news/cma-issues-infringementdecision-against-flynn $>$. 


\section{Actavis}

On 16 December 2016, the CMA issued a Statement of Objections to Actavis in which it set out provisional findings that Actavis had charged excessive prices for hydrocortisone tablets. ${ }^{29}$ The CMA found that Actavis had increased the price of $10 \mathrm{mg}$ tablets by over 12,000 per cent compared to a branded version of the drug that was sold by a different company prior to April 2008. More specifically, the price rose from $£ 0.70$ per pack in April 2008 to $£ 88$ per pack by March 2016. It also found that the prices of $20 \mathrm{mg}$ tablets had increased by nearly 9,500 per cent. In explaining its decision, the CMA also emphasised that the payor had no choice but to buy the drug because it was a life-saving drug that was the primary replacement therapy for people with adrenal glands that do not produce sufficient amounts of steroid hormones.

\section{Licensing agreements}

\section{A. Royalties on invalid/expired patents}

On 7 July 2016, the EU Court of Justice issued a ruling addressing the question of whether EU competition law prohibits the enforcement of a royalty provision in a license agreement where the licensed patent has been held to be invalid. ${ }^{30}$ The question was referred to the Court by the Paris Court of Appeals in the context of its review of an arbitral award that ordered Genentech to pay more than $€ 100$ million in royalties to Hoechst.

The dispute between Genentech and Hoechst concerned a 1992 licensing agreement covering two US patents and one European patent, the latter having been revoked in 1999. The license agreement allowed Genentech to use the licensed technology for research purposes for an annual licensing fee as well as a royalty on the manufacture, use, and sale of the licensed products.

According to Hoechst, Genentech never paid the required royalties. Hoechst notified Genentech that it believed that Genentech was selling products that infringed the licensed patents. Genentech promptly terminated the agreement. Hoechst initiated arbitration proceedings seeking the payment of royalties relating to the sale of the drug Rituxan. The arbitral tribunal found in favour of Hoechst and ordered Genentech to pay

29 Competition and Markets Authority, Press Release, Pharmaceutical company accused of overcharging NHS, 16 December $2016<$ https://www. gov.uk/government/news/pharmaceutical-company-accused-ofovercharging-nhs>

30 Case C-567/14, Genentech Inc. $v$ Hoechst GmbH and Sanofi-Aventis Deutschland GmbH (7 July 2016). more than $€ 100$ million in royalties on the use of the technology in its product even though the use of the technology did not violate Hoechst's patents, which had been revoked. It reasoned that Genentech had agreed to make royalty payments in return for the certainty of avoiding patent litigation, and Genentech had received the benefit of that certainty.

Genentech appealed the arbitrators' decision to the Paris Court of Appeals, seeking annulment of the arbitral award. The Paris Court of Appeals referred to the Court of Justice the question of whether Article 101 prevents a licensor from requiring a licensee to pay royalties for the entire duration of an agreement, notwithstanding the revocation of the licensed patent or the absence of patent infringement.

Before the Court of Justice, Genentech argued that the arbitrator disregarded the terms of the patent license agreements and of Article 101 by requiring it to pay royalties on sales of a product which did not infringe the licensed patents. Genentech submitted that, if it were required to pay royalties, these additional costs would place it at a disadvantage as compared with its competitors, and would distort competition in breach of Article 101.

The Court of Justice rejected this argument, holding that Article 101 does not prohibit a contractual royalty obligation for the use of a technology that is no longer protected by a patent, as long as the licensee is free to terminate the agreement. As Genentech was free to terminate the agreement with Hoechst at any time, the Court found that the royalty obligation did not restrict competition.

\section{B. Coordination among competing suppliers}

In the ongoing Roche/Novartis case in Italy, now on appeal to the Italian Council of State, the Court on 25 March 2016 referred five questions to the EU Court of Justice for a preliminary ruling. ${ }^{31}$ This case arose from appeals against the February 2014 decision of the Italian competition authority imposing fines of $€ 92$ million on Novartis and €90.6 million on Roche for allegedly attempting to restrict competition between two products, Avastin and Lucentis. The Regional Court of Lazio upheld the authority's decision on 5 November 2014, and its judgement was appealed to the Council of State.

31 Request for preliminary ruling from the Consiglio di Stato (Italy) lodged on 25 March 2016, F. Hoffmann-La Roche AG, La Roche SpA, Novartis AG and Novartis Farma SpA $v$ Autorita Garante della Concorrenza e del Marcato, Case C-179/16, OJ (2016) C 222/4. 
The case involves two drugs developed by Genentech that came out of a research programme aimed at finding ways to stop the process of blood-vessel formation called angiogenesis, which feeds tumour growth in cancer patients and also causes certain eye diseases. The first drug to be developed was Avastin, which was designed to treat cancer. A couple of years later, a derivative of the main compound in Avastin was developed into Lucentis, a drug to treat eye disease. Before Lucentis came onto the market, doctors used Avastin on an 'off-label' basis to treat eye disease as well. In other words, even though Avastin was only approved for the treatment of cancer, doctors also prescribed it for treating the eye disease, an unregistered or 'off-label' use.

As Genentech did not have a sales network in Europe, it licensed the products out-Avastin to Roche, its parent company, and Lucentis to Novartis. Avastin was sold at a maximum price of $€ 81$ per injection in Italy, while Lucentis was much more expensive-it started at a price $€ 1,700$ per injection, which was later lowered to $€ 900$. Before Lucentis was launched on the Italian market, Avastin was widely prescribed by doctors on an 'off-label' basis to treat eye disease. The Italian regulatory regime allowed such off-label use of a drug if there was no registered treatment available. Once Lucentis was launched on the Italian market, the off-label use of Avastin for eye disease was no longer reimbursed because there was now a drug available that was registered for the treatment of eye disease. The switch from Avastin to Lucentis for the treatment of eye disease led to a dramatic increase in the cost of treating the eye disease, which generated the complaints by private healthcare clinics and the Italian Ophthalmological Society that led the competition authority to open its investigation.

After a year-long investigation, the competition authority concluded that Roche and Novartis had colluded to prevent Avastin from being used for the treatment of eye disease. More specifically, they had carried out a campaign aimed at artificially differentiating Avastin and Lucentis by raising safety concerns about the off-label use of Avastin to treat eye disease. The authority found numerous communications between the two groups, particularly between the managers of their respective Italian subsidiaries, to this effect as well as internal documents discussing this strategy. It also pointed out that Roche had sought a change to the label of Avastin highlighting the risks of using Avastin to treat eye disease. The two companies also sought to downplay independent studies showing that the two drugs were equivalent. The authority emphasised that Roche had an economic incentive to prevent Avastin from being used off label to treat eye disease because, as Genentech's parent company, it stood to gain more from the royalties paid to Genentech by Novartis for sales of Lucentis than from sales of Avastin.

In their appeal against the decision, Roche and Novartis argued that the restrictions on the off-label use of Avastin were the result of the decision of the Italian regulatory authority and were not caused by an illegal agreement. The evaluations carried out by the Italian and EU regulatory authorities indicated that Lucentis and Avastin are not equivalent for the purpose of treating eye disease. Roche and Novartis also emphasised that the systematic off-label use of drugs is unlawful, particularly in a situation where a drug has been approved for the same therapeutic indication. In short, it would have been unlawful to sell Avastin for the eye treatment under the relevant regulatory rules.

The Lazio Regional Court rejected these arguments and upheld the decision of the competition authority. It brushed aside the regulatory arguments raised by Roche and Novartis by finding that they were outside the scope of its competence and, thus, not relevant to its review of the decision. It then proceeded to find that Avastin and Lucentis were competing products as the file contained evidence that Avastin was used off-label to treat eye disease in competition with Lucentis. Finally, it found that Roche and Novartis had entered into an illegal agreement to prevent Avastin from being used in competition with Lucentis, pointing to evidence in the file of communications to this effect between the parties.

On further appeal, the Italian Council of State has now put questions to the EU Court of Justice relevant to troubling issues in this case. In particular, the Council of State has asked whether parties to a licensing agreement could be regarded as competitors if the licensee is operating on the relevant market solely by virtue of the license agreement. In the decision, the competition authority treated the relationship between Roche and Novartis as a horizontal relationship between competitors, despite the apparent fact that, absent the license, Novartis would not have competed with Roche.

The Council of State has also asked a number of questions relating to the interplay between relevant pharmaceutical regulatory regime and the competition law regime and focusing on the issue of whether a product not approved by the relevant regulatory authorities may nevertheless be included in the relevant market.

\section{Parallel trade}

Ongoing investigations, appeals and legislative initiatives at the national level illustrate that the legality of 
measures to limit parallel trade remain an active issue in the pharmaceuticals industry. These cases also illustrate the ongoing legal uncertainty in this area, with different legal standards applied in different countries. These differing legal standards broadly reflect the fact that parallel trade has different effects depending on the country, with higher priced countries receiving benefits from the parallel trade of lower priced medicines, but with lower priced countries facing disadvantages such as medicine shortages, ${ }^{32}$ higher prices, ${ }^{33}$ and decreased competition among distributors in the local market. ${ }^{34}$

\section{A. Sweden}

In November 2016, the Swedish competition authority announced the rejection of a complaint by a Swedish distributor, ApoEx, alleging that multiple pharmaceutical suppliers and logistical service providers had illegally refused to supply products for export. ${ }^{35}$

Under Swedish law, pharmaceutical suppliers are under an obligation to supply drugs ordered under a retail license (e.g. orders by pharmacies), and such drugs may not be exported outside Sweden. In contrast, pharmaceutical suppliers are not obliged to supply drugs in connection with orders placed under a wholesale license, which may be exported.

ApoEx held both retail and wholesale licences, and had placed large orders from the pharmaceutical suppliers without specifying under which license it was making the purchase. ApoEx claimed that these orders established an ordinary pattern of supply by the pharmaceutical suppliers, including the supply of products for export, and that the pharmaceutical suppliers had abused their respective dominant market positions by later limiting the volume of products supplied to ApoEx.

The Swedish competition authority rejected ApoEx's complaint. First, on the issue of whether the pharmaceutical suppliers were dominant, the authority appeared to adopt a broad market definition under which the suppliers would be unlikely to be dominant. The authority's reasoning is based upon the judgement of the General Court in the GSK Spain case, which indicated that the relevant market for the wholesale of pharmaceuticals for export should be defined broadly to include all products

32 Case C-468/06, Sot. Lélos kai Sia and Others v GlaxoSmithKline AEVE Farmakeftikon Proïton (16 September 2008), para. 68.

33 Pharmaceutical suppliers may refuse to agree to offer lower prices if significant volumes of the products will be resold into higher price markets. The net effect of this is that the lower income countries may not be able to afford as many treatments for their citizens.

34 Consistent with the judgement in GSK Greece, pharmaceutical suppliers implement supply quotas in order to limit parallel trade into higher priced countries. However, these supply quotas may also have the effect of limiting competition among distributors in the local market, because capable of being sold at a profit owing to the price differential between the local and export markets. ${ }^{36}$

Second, on the issue of abuse, the authority rejected ApoEx's claims that there was an established supply relationship between it and the pharmaceutical suppliers with respect to orders for wholesale, which could be exported. In particular, the authority rejected the claim that ApoEx's past orders made without specifying whether the order was for retail or wholesale established such a relationship with respect to wholesale orders. The authority also determined that the pharmaceutical suppliers were not obliged to supply ApoEx as a new customer once ApoEx made it clear that it was making orders pursuant to its wholesale license.

The rejection of ApoEx's complaint is a favourable decision for pharmaceutical suppliers, as it acknowledges that deceptive tactics adopted by wholesalers to obtain products for export do not establish an ordinary course of dealing, requiring pharmaceutical suppliers to continue supplies. The reasoning underlying this decision is broadly the same as that adopted in the UK by Justice Roth in Chemistree Homecare Ltd $v$ Abbvie Ltd. ${ }^{37}$

\section{B. Spain}

In contrast to Sweden and the UK, in Spain, the Supreme Court has adopted a more restrictive approach to measures implemented by pharmaceutical suppliers to control parallel trade.

In a judgement of 4 March $2016,{ }^{38}$ the Supreme Court held in favour of the European Association of Euro-Pharmaceutical Companies (EAEPC) in a case concerning allegations that pharmaceutical suppliers were illegally restricting parallel trade. The case began with a complaint by EAEPC to the Spanish competition authority, alleging that the pharmaceutical suppliers implemented a system of dual pricing in their distribution agreements, pursuant to which lower prices applied to products reimbursed by the Spanish healthcare system, while higher prices applied other sales in order to discourage exports to higher priced markets. EAEPC alleged that these agreements illegally hindered parallel trade in violation of the EU and Spanish competition laws concerning anticompetitive agreements.

distributors will have little incentive to compete for new customers if they are not able to increase their level of supplies.

35 Swedish Competition Authority, Case no. 791/2015 (10 November 2016).

36 Case T-168/01, GlaxoSmithKline Services $v$ Commission (27 September 2006), para. 159

37 Chemistree Homecare Ltd v Abbvie Ltd [2013] EWHC 264, Case no. HC13D00013 (11 February 2013).

38 Spanish Supreme Court, Case 200/2013 (4 March 2016). 
Following a decision by the competition authority rejecting the complaint, EAEPC appealed to the Spanish courts, ultimately leading to the Supreme Court's judgement in which it upheld EAEPC's challenge and rejected the appeal by the pharmaceutical suppliers. In particular, the Court rejected the arguments of the pharmaceutical suppliers that the alleged dual pricing was solely the result of the Spanish pricing and reimbursement laws, instead noting that the applicable laws did not require the pharmaceutical suppliers to sell products for export at a higher price. This reasoning in the judgement is principally based on the prior judgements of the Spanish courts in the Spain Pharma case ${ }^{39}$ as well as the prior judgement of the EU General Court in the GSK Spain case. $^{40}$

In light of this judgement, the CNMC is now required to further investigate EAEPC's complaint, and thus appears likely to open a formal investigation of the distribution systems of the pharmaceutical suppliers involved. A similar investigation has also been ongoing since March 2015 following the earlier judgement of the Spanish Supreme Court in the Spain Pharma case. ${ }^{41}$

\section{Romania}

In Romania, the national competition authority continues to actively prosecute illegal distribution practices and restrictions on parallel trade. In June 2016, the authority announced that it had opened an investigation into revisions to Novartis' distribution system, under which it intended to directly distribute its products to certain pharmacies, in parallel with its traditional distribution system (presumably through intermediate wholesalers). ${ }^{42}$ This case appears to cover similar issues to the ongoing case concerning the direct distribution system of GSK, in which draft commitments were published in September 2015. ${ }^{43}$

\section{Regulations limiting parallel trade}

Due to the shortages caused by the export of medicines from lower income countries, and the legal restrictions

39 National High Court, Case no. 450/2009 (13 June 2011).

40 Case T-168/01, GlaxoSmithKline Services v Commission (27 September 2006), paras 66-70.

41 Spanish Competition Authority, Case S/DC/0546/15 <https://www.cnmc. es/expedientes/sdc054615>.

42 Romanian Competition Council, Press Release, The Competition Council launched for public consultation the report on sector inquiry on pharma market, June 2016 <http://www.consiliulconcurentei.ro/uploads/docs/ items/id11025/utila_farma_iun_2016.pdf $>$.

43 Romanian Competition Council, Press Release, The Competition Council launches for public debates the commitments formulated by S.C. GLAXOSMITHKLINE S.R.L., September 2015 <http://www. placed on the ability of pharmaceutical suppliers to themselves limit parallel trade, national governments in lower income countries have adopted additional regulatory measures to limit parallel trade.

The Commission has acknowledged that 'Member States themselves are best suited to monitor and ensure the continuous supply of medicines in their territory', ${ }^{44}$ and thus that they are entitled to take restrictive measures to address shortages, provided that the measures are necessary for the protection of health and life of humans and do not go beyond what is necessary in order to attain it. ${ }^{45}$ However, the Commission's approach does not seem to be entirely consistent as it frequently second guesses the legality of national measures, which creates undesirable uncertainty.

The following are examples of recent regulatory developments:

- In Italy, pharmaceutical professional associations together with certain regions, the Italian Ministry of Health and AIFA signed a common position on the enforcement of national law. ${ }^{46}$ This position aims at avoiding shortages of drugs based on national obligations requiring wholesalers to guarantee a permanent and adequate range of medicinal products, prohibiting exports by wholesalers in specific circumstances and prohibiting exports by pharmacies to foreign distributors/wholesalers.

- In Romania, the Health Ministry has published a draft order aimed at avoiding shortages by reducing exports. Under the order, the government may ban exports of a drug if there have been shortages for 7 consecutive days. This order will take effect after the National Medicines and Medical Devices Agency confirms that exports are the reason for the shortages as opposed to, for instance, safety issues. ${ }^{47}$

- In Portugal, wholesale distributors of medicinal products for human use must notify their intention to export medicines considered 'at risk of shortage' by the authorities, and provide information on the export operations that have been carried out. In May

consiliulconcurentei.ro/uploads/docs/items/id10394/dezb_angaj_gsk_sept_ 2015_english.pdf>.

44 European Commission, Response to Parliamentary Question E-009560/ 2015 (1 October 2015).

45 European Commission, Response to Parliamentary Question P-002868-16 (13 June 2016).

46 The position adopted is available here (in Italian): <http://www.salute.gov. it/imgs/C_17_notizie_2702_listaFile_itemName_0_file.pdf $>$ (8 September 2016). The text provides an interpretation of the Decree no. 216/2006.

47 Romanian Health Ministry, draft order ('Ministerul Sănătății, Ordin SĂNĂTĂȚII, pentru aprobarea Normelor de aplicare a prevederilor art. 699 pct. 19 și art. 804 alin. (2) din Legea nr. 95/2006 privind reforma în domeniul sănătăţii') (December 2016). 
2016, the European Commission issued a reasoned opinion criticising the lack of transparent criteria for distributors to determine whether the medicinal products were at risk of potential shortage due to parallel trade. According to the Commission, these notification requirements constitute an unjustified restriction on the export of medicines, and the Commission requested that Portugal remove them. ${ }^{48}$

- In Slovakia, a regulation obliges wholesale distributors to notify the government of the export of all human medicines and observe a 30 -day waiting period before exporting them, which would give the government time to react in the event of a shortage. In May 2016, the Commission issued a reasoned opinion finding the duration of the notification disproportionately long and requesting that Slovakia change the law. ${ }^{49}$

- In the Czech Republic, proposed legislation would allow the authorities to monitor and evaluate the risk of shortages for particular medicinal products and to prohibit exports when justified. The legislation also requires distributors to notify their intention to export 'irreplaceable' medicines and imposes a waiting period of 15 days, during which time the authorities may evaluate whether to issue an order prohibiting the export. ${ }^{50}$

\section{Sector inquiries}

Beyond cases and merger investigations, competition authorities in multiple Member States have conducted sector inquiries addressing a broad range of potential issues arising in the pharmaceutical sector, including competition among vaccines, limitations on entry of generics and analogous products, illegal distribution practices, reference pricing, exchange of sensitive information among competitors and competition among pharmacies and wholesalers.

\section{A. Italy}

In May 2016, the Italian competition authority published the results of its sector enquiry into competition in the market for human vaccines (excluding flu vaccines). ${ }^{51}$

48 'May infringement's package: key decisions', European Commission Fact sheet (26 May 2016) <http://europa.eu/rapid/press-release_MEMO-161823_en.htm>.

49 'May infringement's package: key decisions', European Commission Fact sheet (26 May 2016) <http://europa.eu/rapid/press-release_MEMO-161823_en.htm>.

50 European Commission, Response to Parliamentary Question P-002868/ 2016 (13 June 2016).
While the report acknowledges that suppliers have brought new, innovative vaccines to the market, it also notes that the prices have risen significantly over the past 20 years and that the profitability of suppliers is higher than the pharmaceutical sector average.

The report thus proceeds to discuss competition problems present in the sector, including (i) the presence of an oligopoly of only four major suppliers holding 80 per cent of the global market; (ii) the lack of generic vaccines due to IP protection and the high levels of investment required to develop vaccines; (iii) a lack of competition among vaccines for certain diseases; and (iv) a lack of transparency on the part of the suppliers concerning the different prices they charge in different countries depending upon economic factors such as GDP and ability to pay. In response to these problems, the authority recommends action at Italian and EU levels, inter alia, to increase the possibilities for the development of generic vaccines, and ensure that purchasing decisions take into account the therapeutic properties and cost effectiveness of the vaccines, as well as potential therapeutic equivalence with other competing vaccines.

The report also includes statements that, while not clear, could indicate the possibility for the authority to launch individual infringement investigations against suppliers for unfair pricing where prices for mature products steadily increase rather than decline over time, or against confidentiality agreements preventing purchasers from obtaining information on suppliers' pricing in other regions or countries.

\section{B. Romania}

In June 2016, the Romanian competition authority published a 499-page report setting out the results of its sector enquiry into various practices in the pharmaceutical sector, $^{52}$ and highlighting the following issues (among others):

- Low levels of generic penetration in some segments. The report notes that, despite lower prices, generics have failed to achieve high market shares in some segments, in part due to the high marketing spending by pharmaceutical companies, leading doctors to

51 Italian Competition Authority, Press Release, Investigation into human vaccines: a more transparent market on drug costs and prices, 25 May 2016 $<$ http://www.agcm.it/en/newsroom/press-releases/2331-ic50-investigationinto-human-vaccines-a-more-transparent-market-on-drug-costs-andprices.html>.

52 See Romanian Competition Council, Press Release, The Competition Council launched for public consultation the report on sector inquiry on pharma market, June 2016 <http://www.consiliulconcurentei.ro/uploads/ docs/items/id11122/utila_farma_iun_2016_english.pdf >. 
prescribe branded medicines. In response, the report recommends various measures to increase the use of generic medicines.

- Barriers to competition among pharmacies. The report notes that many patients receive discount cards from doctors that could only be used to buy medicines from specific pharmacies. As this practice has led to a high concentration of sales of medicines at only a few pharmacies throughout the country, the report recommends prohibiting this practice.

- Amendments to distribution systems. The report notes recent changes by pharmaceutical suppliers to their distribution systems, including to direct-to-pharmacy distribution systems or to systems using a limited number of distributors. With respect to such changes, the authority highlights that dominant companies must ensure that the revised systems create benefits for pharmacies, hospitals, and patients that are quantifiable (in terms of quality, service, financial benefits, and availability) and that such benefits at least equal to those arising under the prior distribution systems.

In connection with the publication of the report, the competition authority announced an investigation into a potential abuse of dominance by Novartis for its alleged implementation of a pilot direct distribution system for specific pharmacies, while maintaining its traditional distribution system (discussed further above).

\section{Lithuania}

In December 2016, the Lithuanian competition authority announced the results of its sector enquiry into the market for reimbursable medicines. ${ }^{53}$ The findings of the authority include:

- Restrictions on entry by cheaper, analogous products. Entry for analogous but cheaper pharmaceuticals is restricted due to the regulatory framework that favours manufacturers who offer more expensive pharmaceuticals.

- Problems with reference pricing system. While prices of pharmaceuticals are set by reference to the prices in other countries, the authority noted that the prices referenced from other countries were the publicly declared prices, rather than the lower confidential net prices. The authority also noted that reference pricing

53 Lithuanian Competition Council, Press Release, Final conclusions of market study on reimbursable pharmaceuticals, December $2016<$ https:// kt.gov.lt/en/news/final-conclusions-of-market-study-on-reimbursablepharmaceuticals $>$. was not appropriate for Lithuania as it did not encourage suppliers to reduce prices.

- Exchange of sensitive information among suppliers. The current legal framework facilitates the exchange of commercially sensitive information among manufacturers of medicines, affecting both competition and the prices for reimbursable pharmaceuticals.

Based on these findings, the authority recommended measures to: (i) encourage the entry of pharmaceuticals which are analogous, equally efficient, but cheaper; (ii) take into account the lower net prices when referencing prices of pharmaceuticals in other countries; (iii) eliminate the ability of market players to obtain information about prices applied by competitors; and (iv) ensure that consumers are better informed about cheaper, but equally efficient, pharmaceuticals.

\section{Denmark}

In Denmark, the Danish Competition Council published its report in October 2016 of the results of its sector enquiry into the market for the wholesale supply of medicines to hospitals and pharmacies. ${ }^{54}$ With respect to distribution to hospitals, the enquiry found significant competition among wholesalers and by suppliers distributing their products directly. In contrast, with respect to distribution to pharmacies, the enquiry found that there is only limited competition between the two main wholesalers holding over 95 per cent of the market, in part due to regulations limiting price competition and barriers to the entry of new competitors. The report thus recommends remedial measures to increase competition in the market, including (i) reducing existing barriers that prevent new players from distributing medicines to pharmacies; (ii) increasing wholesalers' opportunities to compete on prices charged to pharmacies; and (iii) increasing pharmacies incentives to actively scan the wholesale market and purchase the best value-for-money product in terms of both medicines and service.

\section{E. Bulgaria}

In Bulgaria, the Bulgarian Commission for the Protection of Competition also announced the results of its sector enquiry, which found issues such as a shortage of reimbursed drugs and the lack of an appropriate

54 Danish Competition Council, Report, Serious problems on the market for medicines to pharmacies, 14 October $2016<\mathrm{http}$ ///en.kfst.dk/Indhold-

KFST/English/News/20161014-Danish-Competion-Council-Seriousproblems-on-the-market-for-medicines-to-pharmacies?tc= E54958826ADF4DA190FADFA134162E12>. 
mechanism for regulating exports, which in turn increase the risk of shortages of life-saving drugs for patients in Bulgaria. $^{55}$

\section{Conclusion}

With the settlement cases now largely behind it, it will be interesting to see where the European Commission turns next. The robust use of Article 102 to counter late life cycle management strategies in Servier may be a harbinger of increased enforcement activity with regard to generic entry. National authorities and courts will almost certainly continue to be very active in this sector with pricing likely to continue to be a focus of enforcement activity in light of the concern over the impact of high-priced drugs on national healthcare budgets.

doi:10.1093/jeclap/lpx004

Advance Access Publication 27 February 2017 